\title{
Anaemia in occult intestinal malabsorption
}

\author{
R. WHITEHEAD, R. L. CARTER, AND A. A. SHARP \\ From the Radcliffe Infirmary, Oxford
}

SYNOPSIS Nine patients are described, four men and five women, aged between 14 and 62 years who presented with symptoms of severe anaemia. Deficiencies of iron and folic acid were subse? quently demonstrated in each case. Although malabsorption was not initially suspected, furthe investigations showed an abnormally high excretion of faecal fat in seven cases.

Anaemias which are 'unexplained' or which show a suboptimal response to treatment should bé investigated from the viewpoint of intestinal dysfunction. Such anaemias are not a particularly uncommon problem.

Anaemia is a well-recognized sequel to longstanding intestinal malabsorption, and when associated with obvious fatty diarrhoea the inter-relationship can be easily established. However, recent studies indicate that steatorrhoea can exist without alteration in bowel habit and without obvious abnormality of the stools. These patients with occult steatorrhoea may show a variety of clinical pictures depending on the degree or nature of the malabsorption.

In the past two years we have encountered nine patients presenting with severe anaemia unassociated with symptoms referable to the gastrointestinal tract; seven of them were subsequently shown to have steatorrhoea. In this paper, we describe the clinical and haematological features encountered in these patients.

\section{CASE REPORTS}

CASE 1 A 46-year-old man, with a long history of mild rheumatoid arthritis, had an episode of apparent irondeficiency anaemia successfully treated with Imferon in 1956. For five months before his admission to hospital in 1962, in addition to long-standing symptoms due to the arthritis, he noticed increasing dyspnoea on exertion.

CASE 2 After complaining for many years of listlessness and fatigue, this 25-year-old man developed dyspnoea on exertion which became progressively worse in the month before admission to hospital.

CASE 3 A 14-year-old girl, who attended the outpatient department, described fainting attacks and increasing breathlessness over the previous four months; before this she had apparently been healthy. On examination, she was noticed to be abnormally pale.

Received for publication 17 February 1964.
CASE 4 A woman of 29 in 1960 was thought to have anorexia nervosa. Her blood at that time was norma but no cause could be found for her very low body weight. On admission to hospital in 1962, she reported that fote the past month she had noticed ankle oedema, dyspnoeg on exertion, marked fatigue, and lassitude.

CASE 5 A man of 28 for six months had suffered fron increasing tiredness and breathlessness. He thought tha he had recently lost weight and gave a history of periodia constipation. His hair became grey before puberty.

CASE 6 In 1961 this 59-year-old woman develope $\vec{\oplus}$ pallor, ankle oedema, and fatigue. When her peripherab blood and bone marrow were examined as an out-patien they revealed a frank megaloblastic anaemia. This was. treated empirically with vitamin $B_{12}$ by the patient's own doctor and there was a good haematological responses The $\mathrm{Hb}$ rose to $92 \%$, but the patient remained rathes listless and complained of vague malaise for the next nine months. Then in October 1962 she became increasingli tired, developed palpitations, and experienced marked dyspnoea even at rest. On admission she was found to be grossly anaemic and in congestive cardiac failure.

CASE 7 A 51-year-old woman over the preceding 18 months before examination had became increasinglpo tired and breathless; her tongue became smooth and sore one month before she was admitted to hospital. She described herself as 'pale and anaemic' since the age of $14 \mathrm{~J}$ and at $\mathbf{2 0}$ her hair had turned grey.

CASE 8 A man, aged 62, who had been breathless of exertion for one year, was admitted with symptoms anc signs of pneumonic consolidation of the left lower lobe. On routine examination, he was noticed to be clinically anaemic.

CASE 9 This 51-year-old woman had complained of fatigue and ankle oedema, followed by loss of appetie and dyspnoea on exertion. During the two months before 
admission she noticed that she had developed a yellow skin. Ten years previously, $x$-ray examination had been suggestive of duodenal ulceration, but examination of the blood at this time revealed no abnormality.

Of these nine patients, only one (case 5) had noticed any abnormality of bowel function, a tendency to constipation. All denied any episode of overt bleeding, and only in case 9 was there any reason to suspect a source of occult blood loss. There were no grounds to implicate any drugs, and all patients appeared to be taking an adequate diet.

\section{METHODS AND RESULTS}

RED BLOOD CELLS The initial haemoglobin levels ranged between $22 \%$ and $60 \%$ of normal $(3.3$ to $8.9 \mathrm{~g} . / 100 \mathrm{ml}$.).

The peripheral blood and bone marrow appearances fell into one of three categories:

Group $A$ (cases 2, 3, and 5) Peripheral blood showed gross iron-deficiency changes, with hypochromic and microcytic red cells. The bone marrow was predominantly normoblastic, with obvious iron-deficiency changes but showing a variable number of megaloid and megaloblastic cells.

Group B (cases 6, 7, and 9) Peripheral blood showed numerous fully haemoglobinized macrocytes, with variable poikilocytosis and anisocytosis; megaloblasts were occasionally present. The bone marrow was predominantly megaloblastic.

Group $C$ (cases 1, 4, and 8) In peripheral blood red cells showed a mixed, dimorphic population of hypochromic normocytes and microcytes, and normochromic or hypochromic macrocytes. The bone marrow showed combined iron-deficiency and megaloblastic features.

A feature common to the bone marrows of all cases was the presence of Howell-Jolly bodies.
WHITE BLOOD CELLS Many of the neutrophil leucocytes in the peripheral blood showed nuclear hypersegmentation. In cases 2,4 , and 6 , there was a slight leucopenia $(3,450,2,1000$, and $4,120 / \mathrm{c} . \mathrm{mm}$.). In all the marrows there was evidence of disordered leucopoiesis, with varying numbers of giant metamyelocytes and myelocytes.

PLATElets A mild thrombocytopenia (100,000/c.mm.) was found in case 9. Additional investigations gave the results shown in Table $\mathrm{I}$.

SERUM IRON LEVELS The method described by Jordan (1956) was used. Levels were low in all cases, namely, $<10-56 \mu \mathrm{g} . / 100 \mathrm{ml}$. (normal range 80-250 $\mu \mathrm{g}$. $/ 100 \mathrm{ml}$.).

SERUM VITAMIN $B_{12}$ The method of Boczarow (1961) was used and the levels were normal in all cases, 115 to $820 \mu \mu \mathrm{g} . / \mathrm{ml}$. (normal range 100-800 $\mu \mu \mathrm{g} . / \mathrm{ml}$.).

URINARY EXCRETION OF FORMIMINOGLUTAMIC ACID (FIGLU) AFTER ORAL HISTIDINE LOADING Excretion, determined by the method of Kohn, Mollin, and Rosenbach (1961), was increased in seven cases and not increased in two. In both the latter cases, treatment with iron produced marked macrocytic changes in the peripheral blood and the FIGLU test, repeated in one of them, became positive.

SERUM FOLIC ACID LEVELS These were estimated in cases $4,7,8$, and 9 , and ranged from 1.2 to $2 \cdot 3 \mu \mu \mathrm{g} . / \mathrm{ml}$. (normal lower limit $2.5 \mu \mu \mathrm{g} . / \mathrm{ml}$.).

Barium meal and follow-through radiographs showed no gross gastrointestinal lesions, but a typical small bowel flocculation pattern was seen in three cases.

DAILY FAECAL FAT EXCRETION Specimens were collected over four days with patients on a diet containing $<70 \mathrm{~g}$. fat/day. Abnormally high levels, 12 to $40 \mathrm{~g}$./day, were

TABLE I

SUMMARY OF LABORATORY FINDINGS

\begin{tabular}{|c|c|c|c|c|c|c|c|c|c|c|c|}
\hline $\begin{array}{l}\text { Case } \\
\text { No. }\end{array}$ & $\begin{array}{l}\text { Serum } \\
\text { Iron } \\
(\mu g . / m l .)\end{array}$ & $\begin{array}{l}\text { Serum } \\
\text { Vitamin } \\
B_{12} \\
(\mu \mu g . / \\
100 \mathrm{ml} .)\end{array}$ & $\begin{array}{l}\text { Serum } \\
\text { Folic Acid } \\
(\mu \mu \mathrm{g} . / \mathrm{ml} .)\end{array}$ & $\begin{array}{l}\text { Increased } \\
\text { Excretion } \\
\text { of FIGLU }\end{array}$ & $\begin{array}{l}\text { Barium } \\
\text { Meal and } \\
\text { Follow-through }\end{array}$ & $\begin{array}{l}\text { Faecal } \\
\text { Fat } \\
\text { Excretion } \\
\text { (g./day) }\end{array}$ & $\begin{array}{l}\text { D. Xylose } \\
\text { Absorption }\end{array}$ & $\begin{array}{l}\text { Jejunal } \\
\text { Biopsy }\end{array}$ & $\begin{array}{l}\text { Gastric } \\
\text { Acid } \\
\text { Analysis }\end{array}$ & $\begin{array}{l}\text { Glucose } \\
\text { Tolerance } \\
\text { Test }\end{array}$ & $\begin{array}{l}\text { Faecal } \\
\text { Occult } \\
\text { Blood }\end{array}$ \\
\hline 1 & 29 & 431 & & $+\mathrm{ve}$ & $\begin{array}{l}\text { Flocculation } \\
\text { in small bowel }\end{array}$ & $40 \cdot 4$ & Decreased & $\begin{array}{l}\text { Subtotal } \\
\text { villous } \\
\text { atrophy }\end{array}$ & Normal & Flat & - ve \\
\hline 2 & 45 & 340 & & - ve & Normal & $11 \cdot 3$ & & Normal & $\begin{array}{l}\text { No free } \\
\text { acid }\end{array}$ & & - ve \\
\hline 3 & 33 & 820 & & + ve & Normal & $9 \cdot 9$ & & $\begin{array}{l}\text { Abnormal } \\
\text { villi }\end{array}$ & Normal & & - ve \\
\hline $\begin{array}{l}4 \\
5\end{array}$ & $\begin{array}{l}56 \\
50\end{array}$ & $\begin{array}{l}179 \\
154\end{array}$ & $2 \cdot 3$ & $\begin{array}{l}+ \text { ve } \\
- \text { ve but } \\
\text { later } \\
\text { becoming } \\
+ \text { ve }\end{array}$ & $\begin{array}{l}\text { Normal } \\
\text { Flocculation } \\
\text { in small bowel }\end{array}$ & $\begin{array}{l}13 \cdot 0 \\
12 \cdot 1\end{array}$ & Decreased & $\begin{array}{l}\text { Subtotal } \\
\text { villous } \\
\text { atrophy }\end{array}$ & $\begin{array}{l}\text { Normal } \\
\text { Normal }\end{array}$ & $\begin{array}{l}\text { Flat } \\
\text { Flat }\end{array}$ & $\begin{array}{l}\text { - ve } \\
\text { - ve }\end{array}$ \\
\hline 6 & 45 & 600 & & + ve & $\begin{array}{l}\text { Flocculation } \\
\text { in small bowel }\end{array}$ & $12 \cdot 2$ & & $\begin{array}{l}\text { Subtotal } \\
\text { villous } \\
\text { atrophy }\end{array}$ & Normal & & - ve \\
\hline 7 & 10 & 510 & $1 \cdot 2$ & + ve & Normal & $12 \cdot 9$ & & & $\begin{array}{l}\text { No free } \\
\text { acid }\end{array}$ & Flat & - ve \\
\hline $\begin{array}{l}8 \\
9\end{array}$ & $\begin{array}{l}29 \\
32\end{array}$ & $\begin{array}{l}740 \\
120\end{array}$ & $\begin{array}{l}2 \cdot 0 \\
2 \cdot 1\end{array}$ & $\begin{array}{l}+ \text { ve } \\
+ \text { ve }\end{array}$ & $\begin{array}{l}\text { Normal } \\
\text { Normal }\end{array}$ & $\begin{array}{l}2 \cdot 5 \\
3 \cdot 3\end{array}$ & $\begin{array}{l}\text { Normal } \\
\text { Normal }\end{array}$ & & $\begin{array}{l}\text { Normal } \\
\text { No free } \\
\text { acid }\end{array}$ & & $\begin{array}{l}\text { - ve } \\
\text { - ve }\end{array}$ \\
\hline
\end{tabular}


found in seven patients and normal levels in two patients, normal upper limit $9 \mathrm{~g}$./day.

FRACTIONAL TEST MEALS (HISTIMINE AUGMENTED) OR DIAGNEX TEST No free acid was found in cases 2, 7, and 9, but acid was present in the remaining cases.

D. XYLOSE ABSORPTION TESTS Absorption was reduced in two cases and normal in two.

OTHER INVESTIGATIONS Jejunal biopsy showed partial villous atrophy with cellular infiltration in three cases, an abnormal villous shape in one case, and normal appearances in one case. Glucose tolerance tests showed abnormally flat curves, indicating malabsorption, in five cases.

Serum proteins, serum calcium and inorganic phosphate, and prothrombin times showed slight abnormalities in those patients with excessive faecal fat excretion.

\section{TREATMENT}

In all cases, the response to treatment was highly characteristic, the pattern being dependent upon the type of anaemia initially present:

GROUP A Initially iron-deficiency changes were seen in cases 2,3 , and 5 . These patients received iron, either orally as ferrous sulphate or ferrous gluconate, or parenterally, as Imferon. All showed a small rise in the reticulocyte count which quickly fell away either to normal values or to a slight plateau; the rise in haemoglobin was small. Examination of the peripheral blood now showed waning iron deficiency changes and increasing numbers of normochromic macrocytes, i.e., a mixed, dimorphic appearance. At this stage, an additional folic acid deficiency was demonstrated in all these cases, and folic acid, $5 \mathrm{mg}$. t.d.s., was given. A second reticulocyte response followed and the haemoglobin rose to normal levels.

GROUP B Initially liver factor deficiency changes were seen in cases 6,7 , and 9 . In these the indiscriminate use of vitamin $B_{12}$ before the completion of full investigations produced some confusion. One of them (case 6) had previously shown an adequate haematological response to vitamin $\mathbf{B}_{12}$ alone and had sustained a remission of over 15 months before returning to hospital with a gross macrocytic anaemia, normal serum vitamin $B_{12}$ levels, and a deficiency of folic acid. Of the other two patients, one received vitamin $B_{12}$ alone and the other received vitamin $B_{12}$ and folic acid: in both there was a partial response with disappointing reticulocyte and haemoglobin values, comparable to the patients in group A. At this stage, re-examination of the peripheral blood showed declining macrocytic features but increasing evidence of iron deficiency changes, incomplete treatment again producing a mixed dimorphic blood picture. When iron was added, there was a second reticulocyte response and the haemoglobin returned to normal.

GROUP C Mixed iron and liver factor deficiencies were seen in cases 1,4 , and 8 . Although initially dimorphic, the predominance of iron deficiency changes in these patients prompted the use of iron alone. A poor response followed, and the dimorphic appearances in the peripheral blood $\vec{F}$ became much more pronounced. The anaemia was com- $-\vec{T}$ pletely corrected by giving folic acid in addition to the iron.

As soon as the correct diagnosis was made, all patients $\frac{\overline{\bar{N}}}{\mathrm{~N}}$ were placed on the special diet with supplementary $\overrightarrow{ }$ vitamins recommended by Badenoch (1960). In every $\mathbb{Q}$ case, the haemoglobin and peripheral blood pictures have been fully restored to normal, and have remained so up to the time of writing.

\section{DISCUSSION}

Anaemias complicating overt steatorrhoea are well documented (Witts, 1932; Thaysen, 1935; Cooke, Frazer, Peeney, Sammons, and Thompson, 1948) but we have found no reference to anaemia in cases $\vec{\circ}$ in which intestinal malabsorption is occult. It is now응 clear that this variant is not uncommon. Cooke (1952) reported that in his series one case in five had completely normal bowel habits, and Badenoch (1960) found no disturbance in bowel function in $11 \stackrel{\text { g }}{\stackrel{2}{2}}$ out of his series of 163 patients.

Any of the following changes in the blood may $\vec{\bullet}$ indicate unsuspected intestinal malabsorption.

1 Any 'unexplained' iron-deficiency anaemia in the absence of a source of bleeding, especially when found in men: dietary deficiencies of iron are rare in Britain. It is of interest that all our cases presenting as pure iron-deficiency anaemias were in patients $\mathbb{Q}$ aged 14,23 , and 28 years.

2 Any seemingly straightforward anaemia in which the response to apparently appropriate therapy is suboptimal. An unsatisfactory reticulocyte response, a small rise in haemoglobin, and the development of a mixed, dimorphic peripheral blood picture are all suggestive of intestinal malabsorption. Inadequate response to therapy is not invariable, as vitamin $B_{12}$ can apparently correct a folic acidô deficiency, although such improvement is usually only transient, as, for example, in cases 7 and 9 . In음 case 6 , however, the response to vitamin $B_{12}$ was unusually sustained and, although maintained foro one year, it is interesting that the patient still complained of ill health.

3 A mixed, dimorphic peripheral blood picture ${ }^{N}$ before the start of treatment is strongly suggestive ${ }_{\mathcal{E}}^{N}$ of multiple deficiencies due to malabsorption.0 Cases 1,4 , and 8 show that the two red cell populations are not present in equal proportions, and that the significance of a minority of different cells may be missed. Initially, these patients were treated as 0 pure iron-deficiency states, although subsequento review of their pre-treatment blood films showed艿 definite dimorphic features which were accentuated $\overrightarrow{\mathrm{D}}$ by iron therapy. Finding of neutrophil leucocytes? 
with nuclear hypersegmentation in preparations from an otherwise typical iron-deficiency anaemia is also suspicious.

4 The presence in the bone marrow of a few transitional or frankly megaloblastic cells, in association with iron-deficient normoblasts, is a further indication of a double deficiency. The assessment of these transitional forms is notoriously difficult, and less equivocal features are the presence of Howell-Jolly bodies, and evidence of disordered leucopoiesis (giant metamyelocytes, myelocytes, and band forms).

The laboratory investigation of these cases, once the possibility of an occult steatorrhoea is raised, is complicated, but the FIGLU test has been particularly helpful. In two of the nine patients, faecal excretion of fat was normal, and evaluation of these cases is difficult. No other cause for combined iron and folic acid deficiency was found, and all tests of intestinal absorption were normal. Folic acid and iron may not be effectively absorbed in an isolated group but study of a larger series of such patients is needed to confirm its existence. It is possible that amongst cases of iron-deficiency anaemia showing increased urinary excretion of FIGLU after oral histidine (Chanarin, Bennett, and Berry, 1962) some cases may prove to be due to intestinal malabsorption.
The diagnosis of dimorphic anaemias is not stressed in standard textbooks, and the fact that we have now seen nine cases in a routine laboratory over a period of two years suggests that the problem may be not uncommon. In this retrospective study, the investigation of some of our patients now appears incomplete, and these omissions do stress the importance of thorough investigation of such anaemias of obscure actiology. More cases may come to light as further detailed studies are made and anaemia due to occult intestinal malabsorption may well be as common as Addisonian pernicious anaemia.

We thank the physicians at the Radcliffe Infirmary for their permission to study these cases, and Dr. G. H. Spray for carrying out the serum folic acid estimations.

\section{REFERENCES}

Badenoch, J. (1960). Brit. med. J., 2, 879.

Boczarow, B. (1961). J. clin. Path., 14, 189.

Chanarin, I., Bennett, M. C., and Berry, V. (1962). J. clin. Path., 15, 269.

Cooke, W. T. (1952). In Modern Trends in Gastro-enterolngy, edited by F. Avery Jones, p. 498. Butterworth, London.

-, Frazer, A. C., Peeney, A. L. P., Sammons, H. G., and Thompson, M. D. (1948). Quart. J. Med., 17, 9.

Jordan, A. (1956). Association of Clinical Pathologists Broadsheet No. 14.

Kohn, J., Mollin, D. L., and Rosenbach, L. M. (1961). J. clin. Path., $14,345$.

Thaysen, T. E. H. (1935). Quart. J. Med., 4, 359.

Witts, L. J. (1932). Lancet, 1, 549. 